\title{
Simplified Life Cycle Analysis: A Rural School in La Pampa, Argentina
}

\author{
Mariela I. Marcilese ${ }^{1}$, Jorge D. Czajkowski² \\ ${ }^{1}$ Laboratorio de Arquitectura y Hábitat Sustentable (LAyHS), Facultad de Arquitectura y Urbanismo (FAU), \\ La Plata, Argentina \\ ${ }^{2}$ Universidad Nacional de La Plata (UNLP), La Plata, Argentina \\ Email: layhs@fau.unlp.edu.ar
}

Received 23 May 2013; revised 25 June 2013; accepted 21 July 2013

Copyright (C) 2014 by authors and Scientific Research Publishing Inc.

This work is licensed under the Creative Commons Attribution International License (CC BY).

http://creativecommons.org/licenses/by/4.0/

(c) (i) Open Access

\section{Abstract}

This study case is a rural school in La Pampa, Argentina, where we compare two energy efficiency systems for construction: the local traditional building type and a proposed one, based on passive system design during its life cycle. In addition, we assume that savings of emissions of greenhousegases are valued in terms of Argentina's energy matrix. The efficiency, in terms of energy, involves the consumption for its manufacture (extraction, transport and assembly of materials), construction, maintenance and dismantling, recycling and final disposal of waste. Knowing this information at the preliminary stage can be advantageous to evaluate the selected materials in terms of energy and cost savings to amortize its value over the life cycle, and introduce other types of design. At present, there are significant problems of resource scarcity. The implementation of the analysis of life cycle (LC) should be a significant contribution in the field of construction in reference to awareness about energy conservation and efficiency, and therefore contributing to the sustainable development of societies.

\section{Keywords}

Energy Efficiency; Rural; School; Life Cycle

\section{Introduction}

Cities consume resources and generate waste. The world is going through a shortage period [1] due to climate change and an ever-increasing demand of resources. Considering the great impact that the construction industry has on the environment, the architecture cannot be limited to space design. These challenges are forcing architects to collaborate with other disciplines in a search for positive synergies between systems and minimization of the negative impacts with the common aim of sustainability [2]. As architects, we must explore the passive 
technologies that use renewable energy and appeal to our creative capacity to maximize the potential of resources [3]. An environmentally conscious project is expected to be friendly to the environment, to respond to climate and location determinants, to use low-energy materials, to consume water rationally, to use energy efficiently and incorporate renewable energy and to maintain indoor environmental quality, among other aspects [4]. There are many examples of schools that represent this type of architecture not only in Argentina but also worldwide. Among them, the dorms of Strathclyde University in Glasgow, United Kingdom, dating back from the year 1987, incorporate a passive solar heating system to provide the rooms with thermal comfort. Some schools in Argentina have been built in an attempt to integrate principles of respect for the environment into pedagogic areas, considering the rural context, in order to reduce the impact and to implement climate conditioning strategies that reduce energy demand to heat or cool a building [3]. The analysis of the life cycle of materials is part of the new methodological instruments optimized in the last few years, mainly to tackle likely environmental impacts, for instance, the use of natural resources and emissions to the atmosphere throughout the life cycle of a product from the acquisition of raw material, the production, the use, the treatment and the disposal at the end of its life cycle [5].

\section{Purpose}

The purpose of this work is to carry out a simplified analysis that allows comparing the life cycle of an ideal rural school located in the province of Buenos Aires, Argentina, according to a construction system of local traditional envelope and its improved version.

\section{Methodology}

The ISO 14040 Standard (2006) establishes that the LCA (Life Cycle Assessment) is a technique to determine the environmental aspects and the potential impact associated with a product, which is applied by compiling an inventory of the relevant ins and outs of the system, by assessing the potential environmental impact associated with those ins and outs and by interpreting the results of the inventory phases and the impact in relation to the aims of the study [6]. According to the ISO 14040, the analysis of life cycle consists of four phases:

- Definition of aims and scopes: The purpose of the study and its magnitude, the involved product, etc., are established,

- Inventory analysis (Life Cycle Inventory LCI): The LC implies a series of processes and connected,

- Systems that generate incoming and outgoing fluids (extracted from the natural environment or else emanated by it) thus at this stage energy requirements and efficiency as well as emissions produced in each of the processes and systems are estimated.

The life cycle involves defining explicit time-variant performance service-life measures of durability, maintainability, reparability, adaptability, upgradability, etc., as well as measures of resource impacts, de-constructability, recyclability, reusability, etc. The essence is that most comfort, health, and durability problems originate from a lack of understanding of the building science repercussions of energy flows in a building [7].

- Impact assessment (Life Cycle Impact Assessment-LCIA): According to the results of the inventory, a classification in relation to the observed environmental effects is made.

- Interpretation of results: Interpretation is made following the objectives of the study, and thereupon pertinent decisions are taken.

This method has been developed in terms of the production and industry sector and therefore it requires adjustment if it is to be applied to the construction sector. However, the LCA is a methodology specific but capable of allowing flexible analysis applicable to different areas. In Argentina the Engineer Dr. Pablo Arena is one of the researchers who has ventured into the matter of LCA and has been a source of reference for this work [7]. However, it is worth mentioning that a simplified version of his methodology was developed.

Four stages were defined in order to obtain a clear analysis of the LC of the building (Figure 1).

1) Project, where functional, spatial and technological strategies to be adopted are set out;

2) Materialization, which involves the necessary energy for the construction of the building;

3) Use of the constructed building, where the required energy is estimated for the use of the building.

4) End of life cycle, where the architectonic object reaches the end of its life cycle.

This work emphasizes stages 1, 2 and 3 of the LC. As for stage 4, it is worth mentioning that in our country there is no such a standardized and legislated system for the recovery and/or reuse of materials deriving from the 


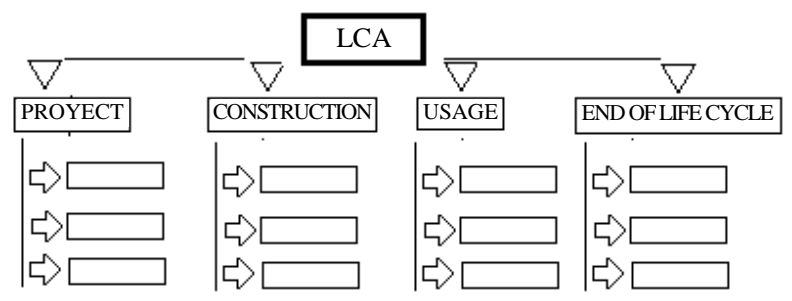

Figure 1. Representative diagram of the life cycle [2].

demolition of buildings.

According to the European experience, the final stage of the life cycle does not usually exceed $5 \%$ of the impacts of the use stage of an existing building. However, this value is variable depending on the type of building, materials, and climatic and geographic conditions, among others [8].

At the first stage, a rural school model was proposed including conscious environmental design strategies (which has the aim to produce sustainable architecture) and recommendations suggested for this bioclimatic region.

At the second stage the energy content of the materials of the envelope generally used locally and of its improved version, which incorporates measures to increase the envelope energy efficiency, was determined.

It is important to note that in the case of Argentina, energy and environmental evaluation of materials and components is a difficult task to accomplish because there is no data available. For this reason in this work information was taken from Spanish bases, specifically the Sustainable Building Guide Institute for Diversification and Saving of Energy IDAE. These data refer to the energy content of the materials in the processes of raw material extraction, manufacturing, processing, associated transport, laying, excluding, for example in transport, the share of the energy invested in building and/or maintenance of infrastructure or necessary means to implement them. Nor is recognized human energy used in labor of various processes mentioned. It is known that in some cases, they may be unrepresentative of local data, however, there is no choice but to use them for this work. They will be replaced and updated in future research.

At the third stage, the AudiCad software [9] was employed allowing a monthly analysis of the thermal and energy performance of the building. The characteristics of the building, such as the occupancy rate, the lighting level, etc., are to be uploaded. The software results show the demand of electric energy and liquefied petroleum gas in sunny and cloudy days. Then, the data is transferred to a spreadsheet to be analyzed. Previous studies concluded that $80 \%$ of the total impact of buildings occurs during the operation stage which is highly influenced by the energy demand for heating [10] [11]. As mentioned before, phase 4 was not taken into account.

\subsection{Project}

The initial phase holds the greatest potential to optimize the project. The most transcendental decisions regarding energy efficiency low cost can be made from the first ideas [7]. The ideal school model is located in the rural area of Dolores (lat $0.36^{\circ}$ long $0.57^{\circ}-6$ masl) Buenos Aires province, Argentina (Figure 2) [12].

This region is classified as zone III mild-warm, sub-zone III-b humid-warm according to IRAM standard 11.60, corresponding to Cfa in the Köppen classification. It is characterized by it's a high relative humidity (ranging from $70 \%$ to $85 \%$ ) and temperature range below $14^{\circ} \mathrm{C}$. For this zone the following design recommendations should be considered:

- Optimum orientation NNW-N-NNE.

- Use of light colours. Roofs need two times more thermal insulation than walls.

- Terrace garden/ventilated facade/Carpentry with mobile sun protection.

- Verify that there is a minimum of two hours of sunlight in the main environments in winter.

- Recommended materials with an average thermal mass of 200 to $300 \mathrm{~kg} / \mathrm{m}^{2}$ [13].

The smallest rural schools generally have 2 to 4 classrooms, a multi-use room with a service area for support, toilettes and a room for the teacher. In this case, a warehouse and an open-air orchard have also been suggested. The school of 225 sqm has only one linear floor plan and the best orientation in the longitudinal facade, where the classrooms and the multi-use room are located (Figures 3 and 4). According to the functions, the floor plan of the project can be analyzed in four sectors: 

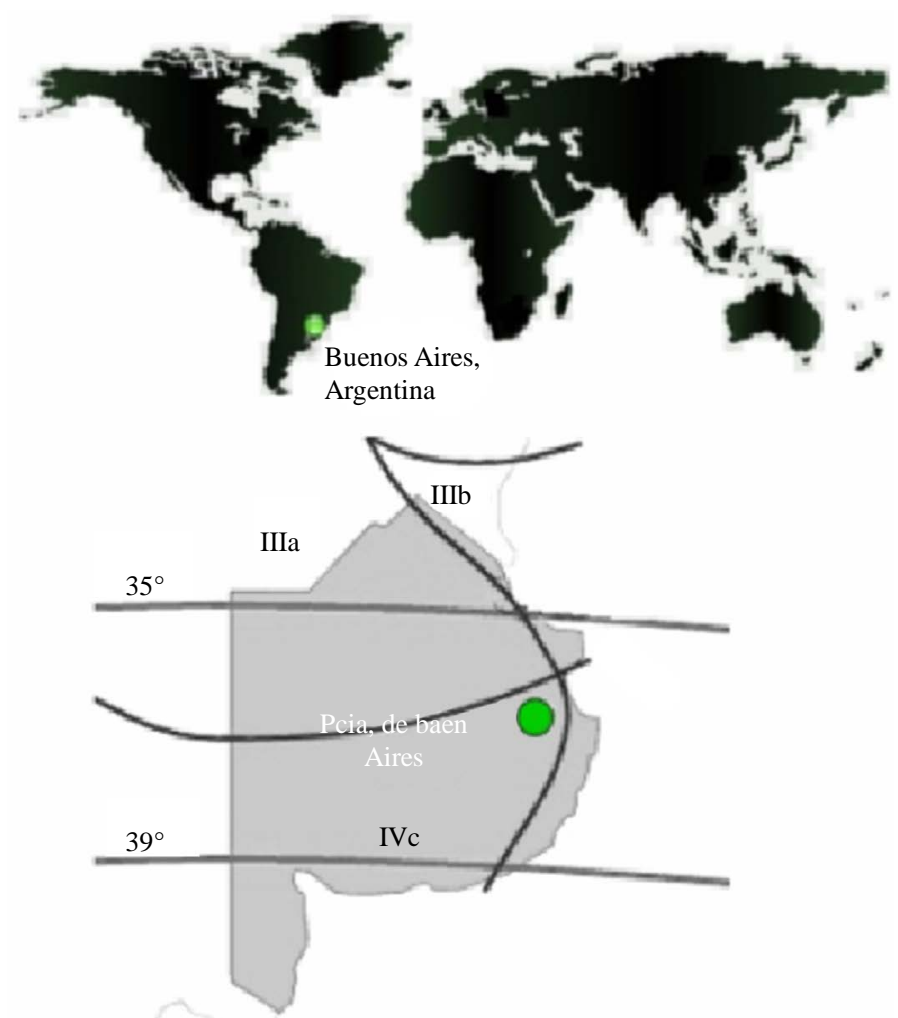

Figure 2. Dolores, province of buenos aires. (IRAM11603. Authors).

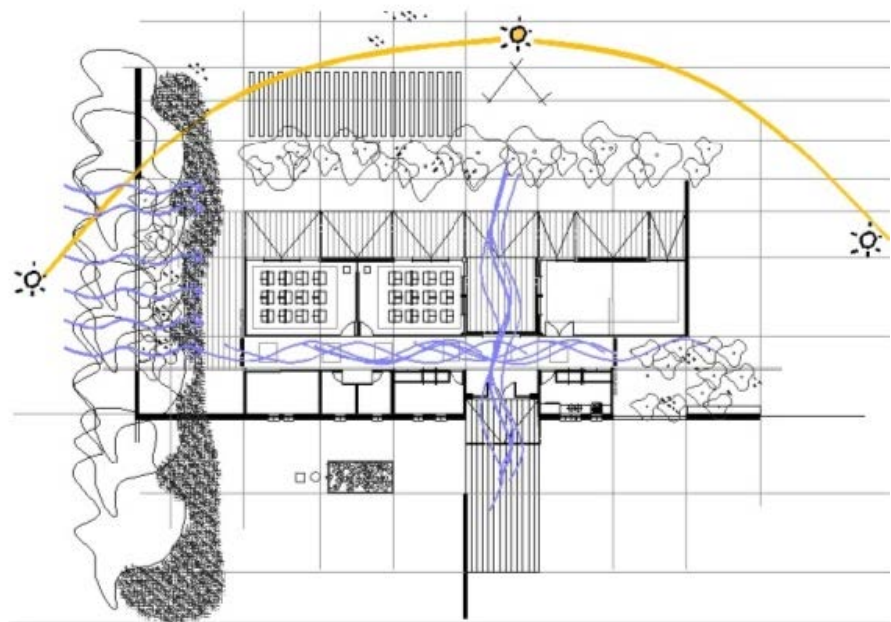

Figure 3. Ideal school floor plan model with environmentally conscious design principles [12].

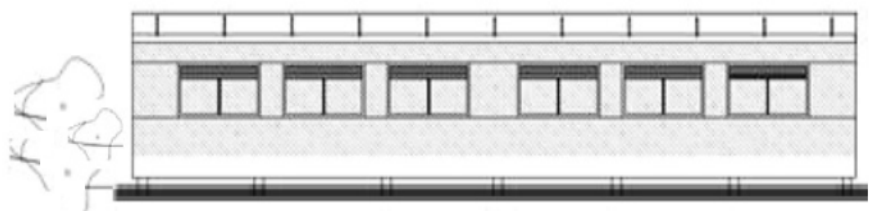

Figure 4. North side. Classrooms sector [12]. Relationship glass/opaque $=0.22$; Relationship glass $/$ area $=0.13$. 
- Circulation: a central space that can be opened at its ends to create drafts to cool the whole building. It has natural zenith lightning.

- Service areas (toilettes, kitchen, and warehouses): oriented to the south. It has a minimum windows area and a protection of natural soil functioning as a thermal mass. On the roof there are solar hot water panels, photovoltaics and water tanks.

- Classrooms and Multi-use room: These rooms get direct sunlight and passive solar systems to heat indoor air. The carpentry includes an independent means of ventilation in the upper section that allows indoor air quality regulation. Temperature and light control is ensured due to a gallery along the northern facade.

- Outdoor areas and indoor patio: They were designed considering the general visual comfort in the building, and simultaneously favouring indoor thermal comfort. There is low-height vegetation to the East and to the South that does not block the sun rays in the morning and does not give shade. Taller trees to block the sun, cool the area in hot weather and produce the opposite effect in cold weather are suggested in the West and the North. In the middle of the floor plan, an indoor patio was proposed to air the core of the building and join physically and visually the adjacent areas.

\subsection{Materialization}

In order to estimate the profitability of an investment, its recovery period must be determined. When it comes to a building, the purpose is to optimize its value during its life cycle, taking into account both its direct and indirect costs. The material selection for a building deeply influences its design and performance. In addition, it must be considered that they have consumed a large quantity of energy even before they were used for the work construction, from their extraction, transport and processing to their placement [2].

\subsubsection{Option Built with Local Traditional Materials (01)}

The materials were selected on the basis of the current report of existing schools in the area and the graphic documentation provided by the Ministry of Education of the Province of Buenos Aires.

- Walls: Rendering $+12 \mathrm{~cm}$ hollow brick masonry + Plastering $\mathrm{U}=1.63 \mathrm{~W} / \mathrm{sqm} \cdot \mathrm{K}$

- Windows: aluminium frame $+5 \mathrm{~mm}$ single glazed $\mathrm{U}=5.8 \mathrm{~W} / \mathrm{sqm} \cdot \mathrm{K}$

- Roofs: metal sheet + thermal insulation with $2.5 \mathrm{~cm}$ thick EP (expanded polystyrene) + tongue and groove pine $\mathrm{U}=0.72 \mathrm{~W} / \mathrm{m}^{2} \cdot \mathrm{K}$

\subsubsection{Improved Option ( 02 )}

Regarding the selection of materials and construction systems, an environmentally conscious building chooses those of lower energy content and greater thermal performance [4]. These characteristics are obtained from the analysis of their manufacturing process which, as noted, is a matter pending in our country so this information should be taken from external databases.

On the other hand, in Argentina, IRAM 11.605 Standard establishes thermal comfort parameters. Law 13059/ 03 Decree-law1030/10 establishes level B as admissible. For winter, level B $20^{\circ} \mathrm{C}$ and level A $22^{\circ} \mathrm{C}$. The implementation of thermal insulation in the envelope is considered one of the forms of thermal energy savings and therefore more effective reducing $\mathrm{CO}_{2}$ emissions to the atmosphere [11]. Other studies find that the greatest reductions in energy consumption are due both to increased thermal insulation and the implementation of windows with the best $U$ values [10].

The materials suggested in this improved construction system would place the school between the categories A and B proposed by the abovementioned standard.

- Walls: rendering $+12 \mathrm{~cm}$ hollow brick masonry + thermal insulation with $5 \mathrm{~cm}$ thick EP (expanded polystyrene) $+8 \mathrm{~cm}$ hollow brick masonry + plastering $\mathrm{U}=0.41 \mathrm{~W} / \mathrm{sqm} \cdot \mathrm{K}$

- Windows: aluminum frame + hermetically sealed double glazed Windows $\mathrm{U}=2.85 \mathrm{~W} / \mathrm{sqm} \cdot \mathrm{K}$

- Roof: metal sheet + thermal insulation with $10 \mathrm{~cm}$ thick expanded polystyrene + air space $\mathrm{U}=0.39 \mathrm{~W} / \mathrm{sqm} \cdot \mathrm{K}$

Following IRAM Standard 11549, the coefficient K or U of thermal transmittance indicates the heat flow through the surface unit of a construction element subject to the $1^{\circ} \mathrm{C}$ difference of air temperature at both sides of the element and it is estimated according to the method and the thermal characteristics of materials and construction layers specified by IRAM Standard 11601. 


\subsubsection{Lighting System}

In Argentina the IRAM Standard AADL J20-06 establishes the minimum lighting levels for more than 200 activities in accordance with the type of building, premises and visual task to be carried out. Such Standard dates back from 1972 and was reedited without any changes in 1996. The values established by it for schools lighting range from 500 Lux. In order to establish the lighting power, low consumption light bulbs were suggested in classroom, service areas, corridors and multi-use rooms.

\subsubsection{Heating System}

In Argentina balanced-flue space heaters are the most common heating system. This equipment consists of an air tight combustion chamber that exchanges air and combustion gases with the outdoor area and only heat with the indoor area of the house through its surface. This type of system neither consumes oxygen nor emits combustion gases indoors. The thermal efficiency of the heat radiated to the indoor area ranges from $40 \%$ to $60 \%$ [14].

\subsection{Usage of the Building}

The weather conditions and the technological characteristics of a building determine the quantity of energy required to air-condition its rooms, both in cold and hot weather. In order to maximise comfort and predict and prevent un-desirable situations, it is important to know its possible thermal performance and the energy requirements [3].

Rural schools in Argentina are not usually connected to all network services, therefore they are supplied by other means. In this particular case, the school was analyzed assuming that it was connected to the electricity network but that its heating system is supplied with liquefied petroleum gas (LPG). As it was mentioned before, the Audit Cad software was used to estimate energy consumption (electricity for lightning and gas for cooking and heating) supposing that all of the rooms in the school were under comfort conditions. The parameters used in the analysis were:

Compactness 0.44

Shape factor 0.84

Exposure factor 0.72

Average outside temperature $10^{\circ} \mathrm{C}$

Indoor design temperature in classrooms $20^{\circ} \mathrm{C}$

Indoor design temperature in service areas, corridor and multi-use room $18^{\circ} \mathrm{C}$

Indoor gain through occupation: 52 people

Indoor gain through lighting:

-400 lux $=16 \mathrm{~W} / \mathrm{sqm}$ in classrooms

$-250 \mathrm{lux}=10 \mathrm{~W} / \mathrm{sqm}$ in service areas, corridor and multi-use room

\section{Results}

According to the traditional construction system and the improved version, energy consumption at the different stages of the building life cycle and carbon dioxide emissions to the atmosphere were analyzed, as well as the loss generated by the envelopes and the contributions of the factors that make up the school thermal charge.

\subsection{Construction Stage: Embodied Energy (EE) and $\mathrm{CO}_{2}$ Emissions $\left(\mathrm{CO}_{2} \mathrm{E}\right)$}

The energy content estimate was obtained from the IDAE (Institute for Energy Diversification and saving) database, which means that the school would be built using both the local traditional system and its improved version. The analysis was conducted per constructed square meter (Table 1) [15].

From the nineteenth century, the carbon dioxide emissions have been exponentially increasing. This increase is to a large extent due to the burning of fossil fuels. In the construction industry, this resource is employed as one of the main sources of energy and therefore, it implies the revision of how buildings are designed and built [16] [17]. An analysis of the carbon dioxide emissions that this school would generate with both construction systems was carried out. Thus, a calculus program created by the U.S. Environmental Protection Agency (EPA) with the Argentinean energy matrix was used. In this regard we must say that the values provided by the EPA calculator "Greenhouse Gas Calculator equivalencies", are for U.S. energy matrix, where much of the power 
Table 1. Construction stage. Embodied energy by $\mathrm{m}^{2}$ (Authors).

\begin{tabular}{ccccc}
\hline & \multicolumn{2}{c}{ EEO1 } & \multicolumn{2}{c}{ EEO2 } \\
\hline ITEM & $\mathrm{kW} / \mathrm{m}^{2}$ & $\%$ & $\mathrm{~kW} / \mathrm{m}^{4}$ & $\%$ \\
\hline Reinforced concrete structure & 0.125 & 38.34 & 0,125 & 35.31 \\
Roof & 0.033 & 10.12 & 0,038 & 10.73 \\
Walls & 0.136 & 14.72 & 0,16 & 44.35 \\
Carpentry & 0.002 & 0.61 & 0,002 & 0.56 \\
Glass & 0.03 & 9.202 & 0,032 & 9.04 \\
Total number & 0.326 & 100 & 0,354 & 100 \\
Difference & & & $0,03 \mathrm{~kW} / \mathrm{m}^{2}$ & $8 \%$ \\
\hline
\end{tabular}

generation is coal. In Argentina, the source of most widespread electricity generation is hydroelectric, which is approximately $50 \%$ cleaner. To use the calculator indicate a value referring for example to "liters of gasoline consumed", "kWh of electricity", "natural gas therms" etc., and it automatically gets the result in carbon dioxide or $\mathrm{CO}_{2}$ equivalent. The results were the following:

$$
\begin{aligned}
& \mathrm{ECO}_{2} \mathrm{O} 1=0.27 \mathrm{TnCO}_{2} / \mathrm{sqm} \\
& \mathrm{ECO}_{2} \mathrm{O} 2=0.31 \mathrm{TnCO}_{2} / \mathrm{sqm}
\end{aligned}
$$

\subsection{Usage Stage: Potential Energy Demand (EE) and $\mathrm{CO}_{2}$ Emissions $\left(\mathrm{CO}_{2} \mathrm{E}\right)$}

The potential energy demand was calculated with the help of the AuditCad software estimating a period of 50 years of the building life cycle. Based on that, the carbon dioxide emissions were calculated using the EPA program abovementioned. It is worth mentioning that neither the energy required for maintenance nor the replacement of construction elements during usage period was considered. Previous studies on LCA considered a 50 years life span of buildings. The aim is to generalize a factor actually varies by type of construction, materials, etc. [10]. If we think of the schools, it is likely that in 50 years will generate large changes in the building, but considering cases analyzed in our country, are always expansions for the original school, therefore, we consider valid to take 50 years as shelf life.

$$
\begin{aligned}
& \text { EEO1 }=29,058 \mathrm{kWh} / \mathrm{m}^{2} \text { per } 50 \text { years } \\
& \mathrm{CO}_{2} \mathrm{EO} 1=11.65 \mathrm{TnCO} / \mathrm{m}^{2} \text { per } 50 \text { years } \\
& \mathrm{EEO} 2=9892 \mathrm{kWh} / \mathrm{m}^{2} \text { per } 50 \text { years } \\
& \mathrm{CO}_{2} \mathrm{EO} 2=3.8 \mathrm{TnCO} / \mathrm{m}^{2} \text { per } 50 \text { years }
\end{aligned}
$$

\subsection{Summary: Potential Energy Demand and $\mathrm{CO}_{2}$ Emissions during LC}

Table 2 shows how the embodied energy and the carbon dioxide emissions vary slightly in both options regarding the initial construction stage. After a year of using the school facilities, a decrease in energy consumption and in carbon dioxide emissions becomes apparent as a result of the improvements. This difference of $66 \%$ remains steady throughout the shelf life of the building resulting in an approximate consumption three times lower with option 2 (O2) and in a proportional difference of emissions to the atmosphere.

During the usage stage of the building, the estimated energy consumption would remain the same both with the traditional and the improved versions given that no changes to the lighting system were suggested. On the other hand, some changes due to the improvement of the envelope were in fact observed in connection with the energy consumption for heating. The values correspond to an annual period (Figure 5).

The school was analyzed following $\mathrm{O} 1$ and $\mathrm{O} 2$. Each case was assumed to have both a favorable (with sunlight) and unfavorable (without sunlight) orientation. It can be seen that during the coldest period (between July and August) the decrease of LPG consumption with the improved version was significant. The months of less 
Table 2. Comparison between embodied energy and $\mathrm{CO}_{2}$ emissions during $\mathrm{LC}$ (Authors).

\begin{tabular}{|c|c|c|c|}
\hline & \multicolumn{3}{|c|}{ EMBODIED ENERGY } \\
\hline & initial & year & 50 years \\
\hline $\mathrm{O} 1$ & $326 \mathrm{kWh} / \mathrm{m}^{2}$ & $58,114 \mathrm{kWh} / \mathrm{m}^{2}$ & $29,058 \mathrm{kWh} / \mathrm{m}^{2}$ \\
\hline $\mathrm{O} 2$ & $354 \mathrm{kWh} / \mathrm{m}^{2}$ & $19,780 \mathrm{kWh} / \mathrm{m}^{2}$ & $9892 \mathrm{kWh} / \mathrm{m}^{2}$ \\
\hline \multirow[t]{3}{*}{ Dif. \% } & $8 \%$ & $66 \%$ & $66 \%$ \\
\hline & & $\mathrm{CO}_{2}$ EMISSION & \\
\hline & initial & year & 50 years \\
\hline $\mathrm{O} 1$ & $0.27 \mathrm{TnCO}_{2} / \mathrm{m}^{2}$ & $0.22 \mathrm{TnCO}_{2} / \mathrm{m}^{2}$ & $11.65 \mathrm{TnCO}_{2} / \mathrm{m}^{2}$ \\
\hline $\mathrm{O} 2$ & $0.31 \mathrm{TnCO}_{2} / \mathrm{m}^{2}$ & $0.075 \mathrm{TnCO}_{2} / \mathrm{m}^{2}$ & $3.8 \mathrm{TnCO}_{2} / \mathrm{m}^{2}$ \\
\hline Dif. \% & $11 \%$ & $66 \%$ & $68 \%$ \\
\hline
\end{tabular}

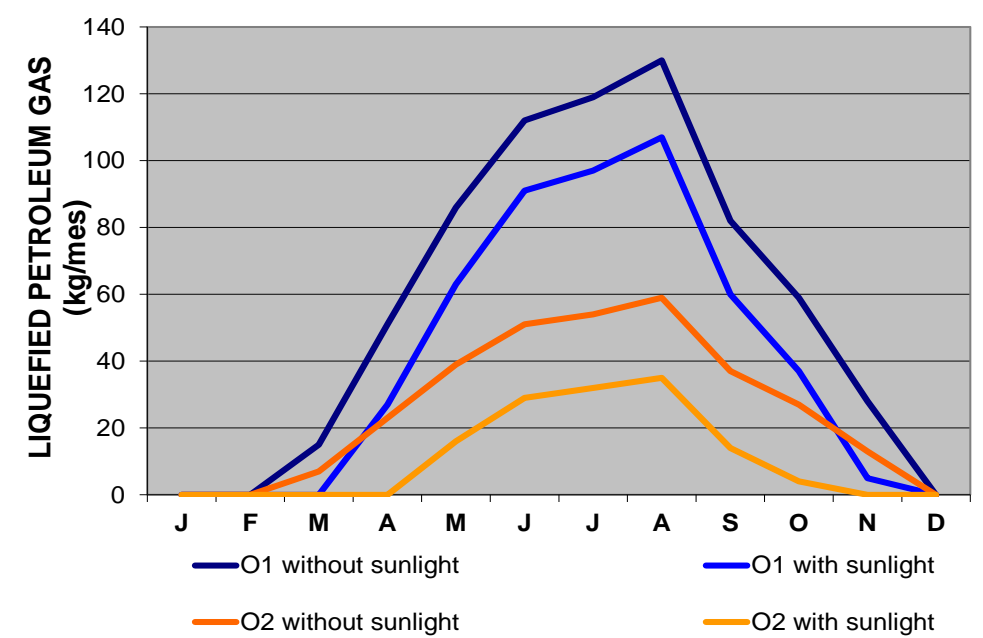

Figure 5. Comparison: consumption of LPG (kg/month) over a year of school building usage (Authors).

heating requirement show an increasing consumption with $\mathrm{O} 1$ and a decreasing one with $\mathrm{O} 2$. Between the two options there is a time lag: with O2, the ignition (theoretical) of the heating system to achieve a level of comfort is delayed approximately 30 days.

From the data obtained from Figure 5 and the HDD18 of the city of Dolores, a consumption index of LPG in Argentina was compiled.

$$
\text { ICLPG }=0.025 \mathrm{kWh} / \mathrm{m}^{2} \cdot \mathrm{y} \mathrm{D}
$$

\subsection{Analysis of the Loss Generated in the Envelope}

In the case of the traditional school the loss through the envelope were distributed in the following way:

- Roof: $39 \%\left(762 \mathrm{~W} /{ }^{\circ} \mathrm{C}\right)$

- Air renewals (2RA): $22 \%\left(426 \mathrm{~W} /{ }^{\circ} \mathrm{C}\right)$

- Walls: $14 \%\left(270 \mathrm{~W} /{ }^{\circ} \mathrm{C}\right)$

- Windows: $18 \%\left(342 \mathrm{~W} /{ }^{\circ} \mathrm{C}\right)$

- Doors: $3 \%\left(54 \mathrm{~W} /{ }^{\circ} \mathrm{C}\right)$

- Floors: $4 \%\left(86 \mathrm{~W} /{ }^{\circ} \mathrm{C}\right)$

With the improved version the loss were distributed in the following way:

- Roof: $10 \%\left(87 \mathrm{~W} /{ }^{\circ} \mathrm{C}\right)$ 
- Air renewals (2RA): $49 \%\left(426 \mathrm{~W} /{ }^{\circ} \mathrm{C}\right)$

- Walls: $7 \%\left(60 \mathrm{~W} /{ }^{\circ} \mathrm{C}\right)$

- Windows: $18 \%\left(161 \mathrm{~W} /{ }^{\circ} \mathrm{C}\right)$

- Doors: $6 \%\left(54 \mathrm{~W} /{ }^{\circ} \mathrm{C}\right)$

- Floors: $10 \%\left(86 \mathrm{~W} /{ }^{\circ} \mathrm{C}\right)$

In Argentina, only natural ventilation is considered in the absence of regulations for the use of heat exchangers and carbon dioxide emissions in school buildings.

Figure 6 shows the difference of loss between the traditional and improved versions. It can be seen that the critical zone of the envelope is in the roof. When making improvements in the construction system the loss through the roof is seven times lower. This loss reduction is also reflected in the vertical opaque envelope and to a lesser extent in windows.

The factors representing the total load of a building (Figures 7 and 8) were analyzed. The analysis reveals that with $\mathrm{O} 1$ the most significant contribution is bottled gas, due to the heat requirements of the school. On the

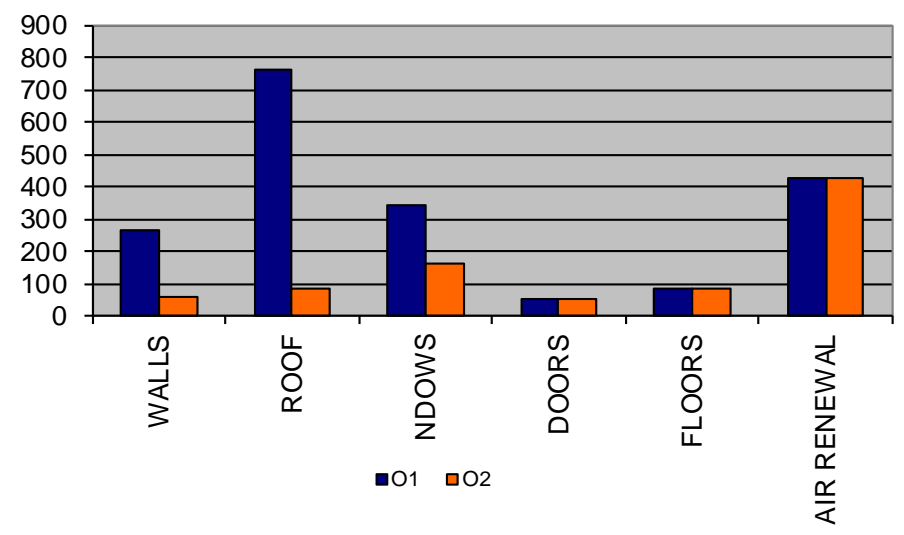

Figure 6. Difference of loss through the envelope (Authors).

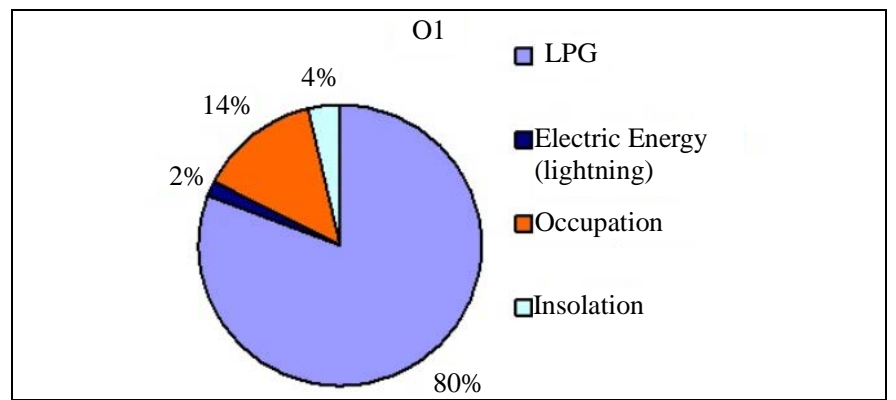

Figure 7. Data uploaded to the AuditCAD for the building design. O1 $=58,114 \mathrm{kWh} / \mathrm{m}^{2} \cdot \mathrm{y}$ (Authors).

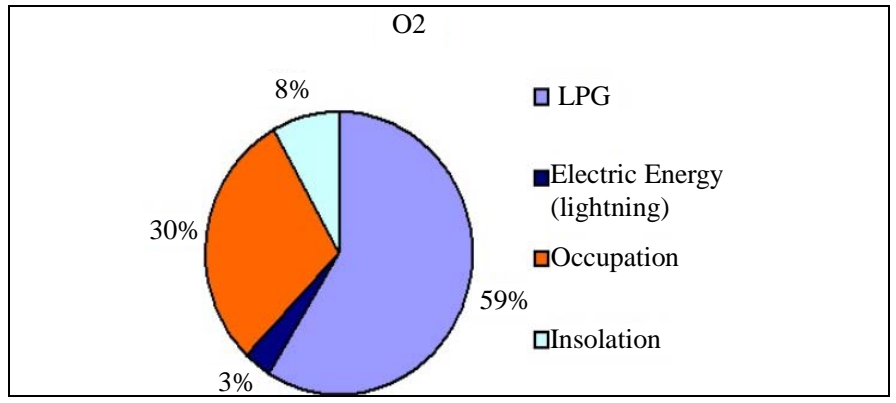

Figure 8. Data uploaded to the AuditCAD for the building design. O2 $=19,780 \mathrm{kWh} / \mathrm{m}^{2} \cdot \mathrm{y}$ (Authors). 
other hand, with the improved option the gas contributions decrease due to an optimization of the envelope and they level with the occupation loads resulting in a more balanced general situation.

Conducting an analysis of consumption and savings from knowing the building life cycle is beneficial with regards to the energy, environment and economy in the long run, particularly to the latter if we consider the fluctuations of the ever increasing energy costs.

From the results, it can be inferred that incorporating a greater quantity of thermal insulation in the envelope would reduce the heating and cooling needs with the consequent financial savings and it would favour a greater balance between heat gain and loss.

The strategies implemented in the improved construction version (period of pre-occupation) are measures readily accepted by professionals of construction and labor management, and therefore their implementation in local school buildings would be feasible.

The increase in energy consumption and carbon dioxide emissions resulting from the improved version in the pre-occupation stage are not very significant if considering the energy that the school would consume during the next fifty years of shelf life (approximately a third of the consumption with the traditional option).

From the analyzed variables, the suggested improvements could be justified but it would be pertinent to complement this work with an analysis of costs and recovery period.

\section{Conclusion}

This simplified analysis of the life cycle of the building can generate ideas to reduce energy consumption and carbon dioxide emissions, reduce or promote the use of certain materials and give a general notion of the building performance in a short period of time and at a low cost.

\section{Acknowledgements}

The authors wish to thank Arch. Maria Belen Salvetti for her assistance with the calculations of the AuditCad program, which was of great importance for the development of this project.

\section{References}

[1] Peris Mora, E. (2007) Life Cycle, Sustainability and the Transcendent Quality of Building Materials. Building and Environment, 42, 1329-1334.

[2] Arena, P., del Ciclo de Vida del Edificio, A. and de los Edificios, S.A. (2005) Experiencias en Argentina. Laboratorio de Ambiente Humano y Vivienda, Mendoza.

[3] Filippin, C. (2005) Termal Response of Solar and Conventional School Building to Design- and Human-Driven Factors. Renewable Energy, 30, 353-376. http://dx.doi.org/10.1016/j.renene.2004.05.012

[4] Rosenfeld, E., Díscoli, C. and Romero, F. (1977) Edificios. Inteligentes. Argentina.

[5] Rogner, H.-H., Zhou, D., Bradley, R., Crabbé, P., Edenhofer, O., Hare, B., Kuijpers, L. and Yamaguchi, M. (2007) Climate Change 2007: Mitigation. Contribution of Working Group III to the Fourth Assessment Report of the Intergovernmental Panel on Climate Change. Cambridge University Press, Cambridge, New York.

[6] IOS (2006) ISO14040:2006 Environmental Management. Life Cycle Assessment. Life Cycle Interpretation. International Organization for Standardization.

[7] Arena, P. and De Rosa, C. (2003) Life Cycle Assessment of Energy and Environmental Implications of the Implementation of Conservation Technologies in School Buildings in Mendoza-Argentina. Building and Environment. The International Journal of Building Science and Its Applications, 38, 359-368.

[8] Nemry, F., Auihleina, A., Colodel, C., Wetzel, C., Braune, A., Wittstock, B., Hasanc, I., Kreißig, J., Gallond, N., Niemeier, S. and Frechc, Y. (2010) Options to Reduce the Environmental Impacts of Residential Buildings in the European Union-Potential and Costs. Energy and Buildings, 42, 976-984. http://dx.doi.org/10.1016/j.enbuild.2010.01.009

[9] Czajkowski, J. (1999) Programa AuditCad para el Análisis del Comportamiento Energético Edilicio Basado en Auditorías Energéticas y de Confort. V Encontro de Conforto no Ambiente Construido, Fortaleza, 6 p.

[10] Dylewski, R. nd Adamczyk, J. (2011) Economic and Environmental Benefits of Thermal Insulation of Building Externals Walls. Building and Environment. The International Journal of Building Science and Its Applications, 46, 26152623.

[11] Utamaa, A. and Gheewala, S.H. (2008) Life Cycle Energy of Single Landed Houses in Indonesia. Energy and Buildings, 40, 1911-1916. http://dx.doi.org/10.1016/j.enbuild.2008.04.017 
[12] Marcilese, M. and Czajkowski, J. (2009) Pautas de Diseño Ambientalmente Consciente para Escuela rural en Microclima Platense. Avances en Energías Renovables y Medio Ambiente, 13, Impreso en la Argentina.

[13] Czajkowski, J. and Gómez, A. (2009) Arquitectura Sustentable. Editorial Clarín.

[14] Gonzalez, A., Juanicó, L. and Gortari, S. (2008) High-Efficiency Prototypes of Commercial Gas Heaters Extensively Used in Argentina. Science Direct. International Journal of Hydrogen Energy 33, 3471-3474.

[15] (1999) Instituto para la Diversificación y Ahorro de la Energía IDAE, Ministerio de Fomento y Fundación Privada Institut Ildefons Cerdá. Guía de Edificación Sostenible. Calidad Energética y Medioambiental en Edificación.

[16] Edwards, B. (2005) Guía Básicos de la Sostenibilidad. Gustavo Gili, Barcelona.

[17] Gonzalez, A. (2010) Comparación de Energías y Gases de efecto Invernadero en Calentamiento de agua para Cocción de Alimentos con Electricidad y Gas Natural. Avances en Energías Renovables y Medio Ambiente, ASADES. 